\title{
Biomarkers aid understanding of aquatic organism responses to environmental stressors
}

\author{
Inge Werner \\ Stephen L. Clark \\ David E. Hinton \\ $\nabla$
}

Biomarkers can be useful tools for understanding the complex interactions that govern organism responses to environmental stressors and their sublethal effects on organism health. We conducted studies on two types of biomarkers: stress proteins and tissue alterations. A study on the freshwater fish medaka demonstrates that the ability to increase cellular stressprotein concentrations at specific life stages can be vitally important for normal embryo development. A field study on Asian clam investigates the usefulness of stress proteins and histopathology as indicators of exposure to and sublethal effects of environmental stressors in the northern San Francisco Bay and Delta.

xposure to environmental stressors
can result in biochemical, physi-
ological and histological (tissue) altera-
tions in living organisms. The presence
of these alterations may serve as "bio-
markers," signaling exposure to stres-
sors or adverse effects, which can range
from molecular, cellular and tissue dam-
age to genetic alterations. In the aquatic
environment, such stressors can con-
stitute changes in physical parameters
such as temperature, pH or salinity, as
well as toxic concentrations of chemical
pollutants or any combination of these.
In the Sacramento-San Joaquin River
watershed, populations of finfish are
in decline (Bennett and Moyle 1996),
and numerous aquatic species are ei-
ther listed or proposed for listing as
threatened or endangered. These in-
clude Sacramento splittail (Pogonichthys
macrolepidotus), delta smelt (Hypomesus
transpacificus), spring- and winter-run
chinook salmon (Oncorhynchus tshaw-
ytscha), coho salmon (Oncorhyn-chus

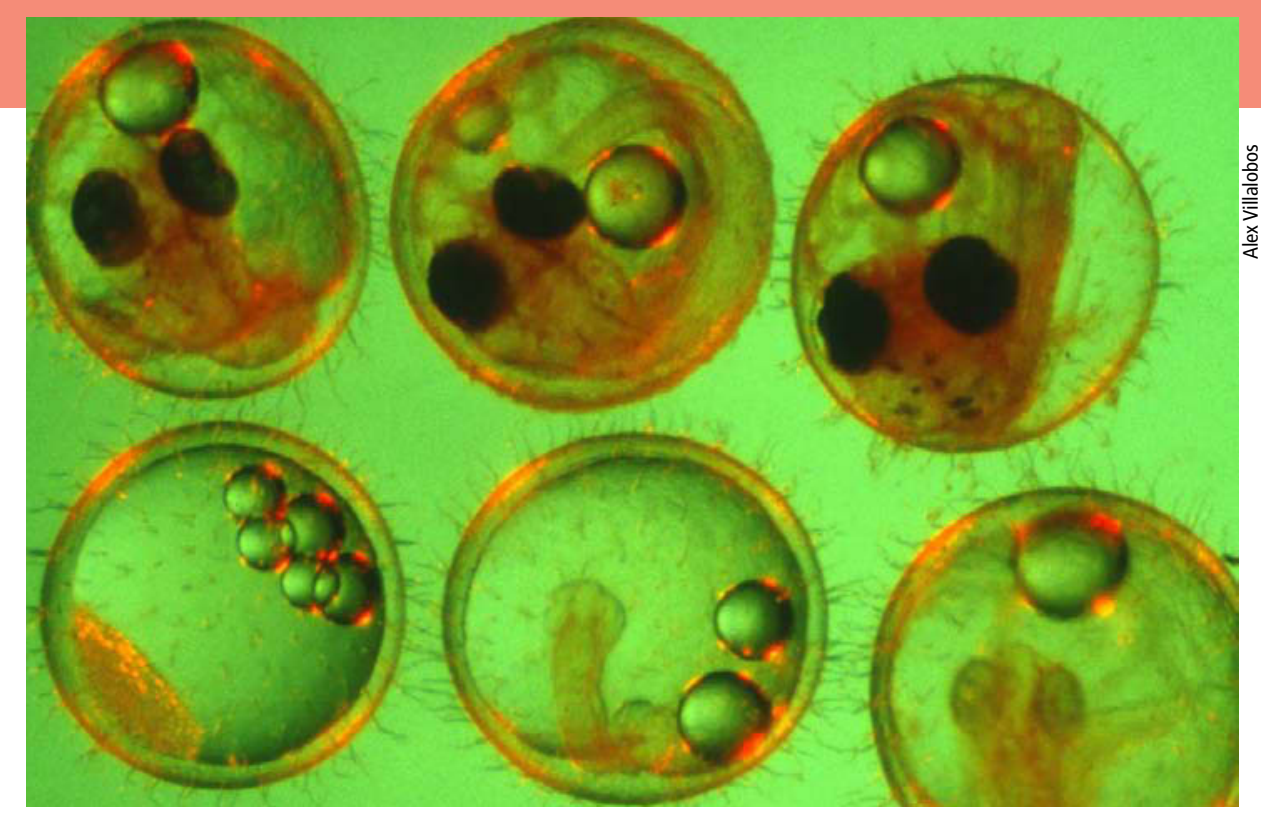

To better understand how stress proteins affect fish, medaka embryos at various stages of development, above, were subjected to heat shock. Stress proteins can serve as biomarkers, indicating exposure to environmental stresses such as temperature, $\mathrm{pH}$, chemical pollution or salinity. Clockwise from upper left: stages 11, 19, 23, 26, 28 and 35.

kisutch) and steelhead trout (Oncorhynchus mykiss). Fisheries experts agree that survival of juvenile fish is a critical factor in maintaining healthy fish populations. Living in an environment that has been altered considerably by human activities, fish are often exposed to a multitude of stressors. Land-use patterns and regulated river flows have changed the temperature, flow and salinity in watersheds (Bennett and Moyle 1996). In addition, toxic contaminants and nutrients enter the water via agricultural and urban runoff, discharges from abandoned mines and point-source dischargers (U.S. Geological Survey 1998;

Werner, Deanovic et al. 2000; Roth et al. 2001).

The ability to protect cells at specific life stages can be vitally important for the normal development of organisms. Knowing the course of development, or ontogeny, of biomarkers shown to be important in adult stress responses, and their importance for normal embryo development, can improve understanding of the specific needs of these organisms for successful recruitment. Some biomarkers, such as the activity of enzymes like acetylcholine esterase or the cellular concentrations of metalbinding proteins (such as metallo-thioneins), enable scientists to determine if exposure to particular environmental

\section{Glossary}

Biomarkers: Biochemical, physiological or histological indicators of either exposure to or effects of physical stressors or xenobiotic chemicals at the suborganismal or organismal level (Huggett et al. 1992).

Histopathology: The study of lesions (alterations) in certain tissue types, including necrosis, inflammation and degeneration (Huggett et al. 1992).

Stress proteins/heat-shock proteins [hsp]: A family of proteins that protect organisms from environmentally induced cellular damage. Members of the hsp70 protein family are involved in the stabilization of unfolded protein precursors, translocation of proteins across cellular membranes, dissolution of protein aggregates, and repair or degradation of damaged proteins. Several hsp70 proteins are always present in cells, while others are only produced in response to stressful environmental conditions (Feige et al. 1996). 
stressors has triggered biochemical and cellular responses in the organism.

Such responses allow preliminary assessments of the impact and bio-availability of a specific type of stressor, but presently cannot provide specific information on higher effects such as survival or reproduction. Other biomarkers, such as cellular stress-

protein levels, indicate that potentially harmful effects have occurred inside cells, and that cellular repair mechanisms have been activated. Finally, tissue damage can indicate effects at the organ level and provide insight into the organism's health. These higher-tier biomarkers are often less stressorspecific, but can reflect the combined effects of multiple stressors. On the other hand, they are often difficult to interpret, especially when applied individually in field studies. To reduce variability in field studies, cause-effect relationships between biomarkers and stressors are best examined using sessile organisms, such as shellfish, which do not move around and reflect conditions at a specific location. However, multiple stressor effects in the field can slow attempts to interpret biomarker responses. We conducted several studies in the field and laboratory to further elucidate the use of biomarkers as indicators of exposure to environmental stressors in the northern San Francisco Bay and Delta.

\section{Stress proteins protect medaka}

To date, the linkage between the age-dependent sensitivity of aquatic organisms to stressors and cellular stress responses is poorly understood. UC Davis researchers (Marty et al. 1990; Hamm et al. 1998) have determined that the sensitivity of fish embryos to toxic compounds is age-dependent and not related to differences in uptake rate or bioavailability, which determines how much of the chemical is taken up by the organism. Often this sensitivity is a function of the organism's ability to metabolize the chemical or activate cellular stress responses and repair mechanisms. The stress-protein response is among the mechanisms that protect organisms from environmentally induced cellular damage. Presence or absence of these protective proteins at a given develop- mental stage may influence how the organism is affected by exposure to physical environmental changes and/or toxic chemicals.

To elucidate the protective role of stress proteins in the embryonic development of fish, we characterized the response of the hsp70 protein family to heat-shock in several developmental stages of the freshwater fish medaka (Oryzias latipes)(Werner, Koger et al. 2001). Medaka are small, easily cultured fish that produce eggs year-round. Their continuous production and availability of eggs, transparent chorion (eggshell) and relatively small adult size facilitate studies of reproductive and developmental effects.

Embryos were obtained from a medaka colony continuously maintained at UC Davis since 1986. At each of five developmental stages, embryos $(n=100$ per stage) were given a

30-minute heat-shock at $104^{\circ} \mathrm{F}$ and returned to culture conditions. Control embryos were maintained at $77^{\circ} \mathrm{F}$. Samples of 10 heat-shocked and

10 control embryos were then taken for hsp analysis at 1, 2, 3, 6, 12 and

24 hours after heat-shock. Proteins were analyzed by gel electrophoresis and immunoblotting using specific antibodies that detect hsp70 (Affinity Bioreagents, Golden, Col.)(fig. 1). Hsp70 proteins were visualized using a chemoluminescent reagent, and subsequently measured by densitometry. For the study of developmental effects and hatching success, 50 embryos per stage were heatshocked as described, then maintained at culture conditions until hatching. De-

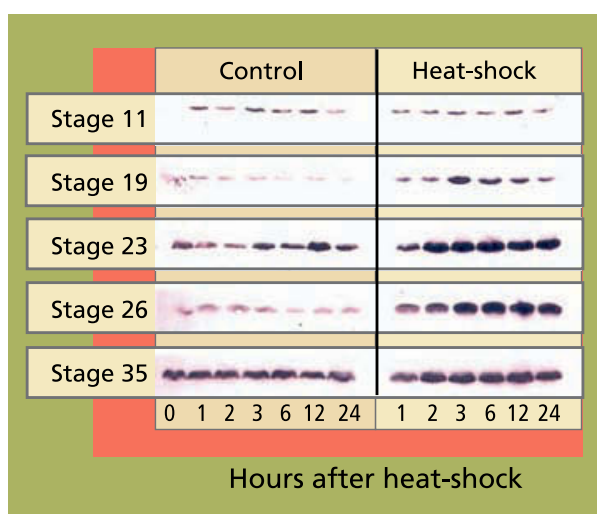

Fig. 1. Western blots of stress protein hsp70 in heat-shocked ( 30 minutes, $\left.104^{\circ} \mathrm{F}\right)$ and control embryos at different stages of development. Each band represents one pooled sample of five embryos. Band intensity reflects cellular concentrations of hsp70 proteins.

velopment and viability were recorded daily.

In early-stage embryos (stage $11=$ early gastrula), stress-protein (hsp70) concentrations did not increase in response to heat-shock (fig. 1), while hsp70 proteins were induced in all other developmental stages. These early-stage embryos were considerably less tolerant to heat stress than embryos at stage 19 and older (table 1). Of stage 11 embryos heat-shocked at $104 \infty \mathrm{F}$ for 30 minutes, 22\% died within 1 day. By day 3 another $22 \%$ died. By day 4 another $28 \%$ showed retarded development when compared to controls, with the formation of large, clear spaces around the heart and over the yolk sac. In addition, eyes were absent or fragmented. These alterations have also been described in medaka embryos exposed to various toxicants (Marty

\begin{tabular}{|c|c|c|}
\hline $\begin{array}{l}\text { Embryonic stage } \\
\left(104^{\circ} \mathrm{F} / 30 \text { minutes }\right)\end{array}$ & $\begin{array}{l}\text { Control/normal development } \\
\text { at time of heat-shock }\end{array}$ & $\begin{array}{l}\text { Development/mortality } \\
\text { after heat-shock }\end{array}$ \\
\hline 11 & $\begin{array}{l}\text { Late blastula/early high gastrula, } \\
\text { stage of rapid cell division }\end{array}$ & $\begin{array}{l}28 \% \text { hatched: } \\
20 \% \text { normal, } 8 \% \text { curved spines }\end{array}$ \\
\hline 19 & $\begin{array}{l}\text { Neuralation, body axis formed } \\
\text { (within } 2 \text { to } 3 \text { days) }\end{array}$ & $\begin{array}{l}100 \% \text { normal; } \\
52 \% \text { hatched early }\end{array}$ \\
\hline 23 & Heart begins to beat & $94 \%$ normal, $6 \%$ helmet heads \\
\hline 26 & Eyes become pigmented & $94 \%$ normal, $6 \%$ helmet heads \\
\hline 35 & $\begin{array}{l}\text { Gallbladder and swim bladder } \\
\text { are formed, rapid yolk utilization }\end{array}$ & $100 \%$ normal \\
\hline Embryo/control I* & & $100 \%$ normal \\
\hline Embryo/control II* & & $100 \%$ normal \\
\hline
\end{tabular}


et al. 1990), and represent pericardial edema, yolk sac and peritoneal edema, and microphthalmia (reduced growth of the eyes resulting in small eyes or blindness), respectively. Only $28 \%$ developed normally.

Hatching began after 7 days, and by day $14,93 \%$ of normally developed embryos had hatched. Of the hatched larvae, 23\% had curved spines. Stage 19 embryos heat-shocked at $104^{\circ} \mathrm{F}$ for 30 minutes developed normally, but initiated hatching earlier than the embryos heat-shocked at later stages and the control embryos. Eighty percent hatched on day 7 of development whereas hatching had occurred in only $0 \%$ to $14 \%$ of all control embryo groups. By day 9 , all embryos heat-shocked at stages 19 to 35 and control embryos hatched, and showed no sign of developmental lesions. However, a small percentage of stage 23 and stage 26 embryos showed "helmet heads," which occurs when all but the head emerges from the chorion and this structure remains closely attached to the head.

The stress-protein response is one of the most important cellular mechanisms to prevent and repair the adverse effects of thermal stress, some chemical pollutants and disease (Feige et al. 1996). Aquatic organisms respond to temperature stress and toxicant exposure by increasing cellular concentrations of hsp70 and related stress proteins (Sanders 1993; Iwama et al. 1998). Among the chemicals shown to produce this response are dioxin (Soimasuo et al. 2001), heavy metals (Baumann et al. 1993) and pesticides (Werner and Nagel 1997). Cellular stress-protein concentrations also increase in response to bacterial and viral infections (Zuegel and Kaufmann 1999).

The inability of early (stage 11) embryos to increase cellular concentrations of stress proteins may render them more susceptible to a variety of environmental stressors during a critical phase of their life cycle. It is of crucial importance that environmental decisionmakers are aware of this when setting water-quality criteria for the protection of aquatic life. Protecting only the juvenile or adult organisms may not guarantee the survival of populations.
Asian clam and environmental stress

The Asian clam, or Amur River corbula (Potamocorbula amurensis), was introduced via ship ballast water into San Francisco Bay in the mid-1980s. The species has since spread prolifically throughout the Bay and SacramentoSan Joaquin River Delta, increasing to a peak population density of more than 12,000 per square yard (Carlton et al. 1990). It has become the dominant species in northern San Francisco Bay (Nichols et al. 1990), where it is implicated as the possible cause of a change in the existing community structure, reducing food supplies for juvenile fish (see p. 104)(Werner and Hollibaugh 1993; Kimmerer and Orsi 1996; Feyrer 2000).

Because of its abundance and wide distribution, UC Davis and the U.S. Geological Survey (USGS) have been studying Asian clam as an indicator species for pollutant effects in San Francisco Bay. Biomarkers of reduced health

including lowered condition indices and energy reserves, and elevated levels of metal-binding proteins - have been observed to increase from San Francisco Bay eastward toward the

Sacramento-San Joaquin River Delta. These indicators were partially linked to heavy metals, particularly cadmium, measured in clam tissues (Brown and Luoma 1995; Teh et al. 1999).

In this study, we attempted to link levels of stress proteins and tissue damage in field-collected Asian clam to concentrations of heavy metal in tissues (Werner and Hinton 1999, 2000). From July 1996 to January 1998, clams were sampled monthly (except October 1996, January to March 1997 and October 1997) from each of four stations in northern San Francisco Bay (fig. 2). Average salinities during the collection period ranged from $4.2 \pm 4.0$ parts per trillion (ppt) at station 4.1 (range: 0.06 to $15 \mathrm{ppt}$ ) to $22.3 \pm 5.6 \mathrm{ppt}$ at station 12.5 (range: 4.1 to $30 \mathrm{ppt}$ ).

Laboratory exposures to dissolved cadmium were conducted to validate results observed in the field and hsp70 proteins were analyzed as described previously. In Asian clam, the antibody

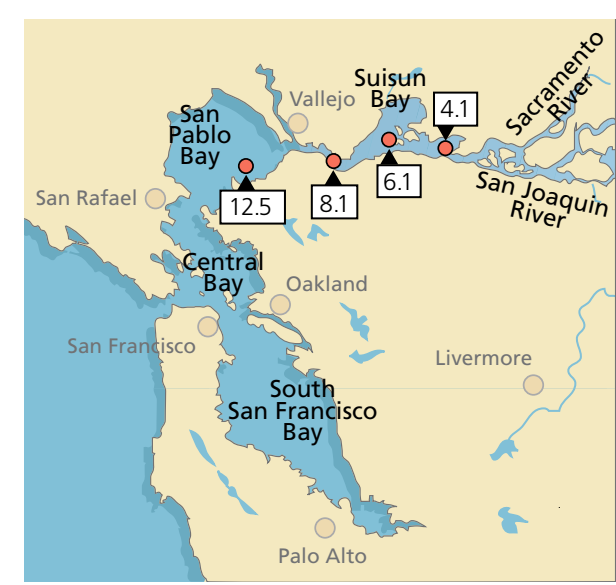

Fig. 2. Asian clam collection sites in northern San Francisco Bay.

used recognized two related proteins, hsp70 and hsp76. For an assessment of histological damage in reproductive organs and gills, clam tissues were scored for severity of pathological alterations as $0=$ none, $1=$ minimal, $2=$ moderate and $3=$ severe.

\section{Stress proteins and tissue damage}

Data obtained for field-collected clams showed that tissue levels of hsp70 were significantly $(P<0.001)$ higher from stations with the lowest cadmium concentrations and highest salinities (12.5 and 8.1) than from stations with the highest cadmium concentrations and lowest salinities (4.1 and 6.1; fig. $3 \mathrm{~A})$. The laboratory results, on the other hand, showed that clams increase their cellular hsp70 levels with increasing cadmium concentrations (fig. 3B). Other heavy metals such as chromium-VI also induced hsp70 proteins. Histopathologic lesions in the testes (chronic inflammation with associated focal necrosis) were relatively common at station 4.1 (high cadmium, low salinity), especially during late spring and early summer (data not shown), and were rare at station 12.5 (low cadmium, high salinity) throughout the year (fig. 4A). Focal necrosis of the ovary and mucuscell swelling in gills followed a similar pattern. A 14-day laboratory exposure of clams to dissolved cadmium caused increased lesion scores in the gills and ovaries (fig. 4B).

Contrary to our expectations, stressprotein levels, which increased with rising cadmium concentrations in our laboratory experiment, were lowest in 
TABLE 2. Hsp70 levels in clams after 3-day laboratory exposure to various salinities*

\begin{tabular}{cl}
\hline \hline Salinity & Hsp70 \\
\hline $0.1 \mathrm{ppt}$ & $16.64 \pm 1.79 \mathrm{a}$ \\
$10 \mathrm{ppt}(\mathrm{ambient})$ & $25.02 \pm 6.70 \mathrm{a}$ \\
$27 \mathrm{ppt}$ & $34.72 \pm 3.31 \mathrm{~b}$ \\
\hline * Clams were collected from Martinez marina \\
(salinity $=10 \mathrm{ppt})$. Letters indicate significantly \\
different groups $(\mathrm{P}<0.05)$.
\end{tabular}

clams from station 4.1 (high cadmium, low salinity) and highest at station 12.5 (low cadmium, high salinity), while physiological indicators of reduced health such as condition index (Teh et al. 1999) and the severity of tissue damage (Clark et al. 2000) suggested that the health of clams at station 4.1 was compromised. In addition, cadmium tissue concentrations and levels of metalbinding proteins were highest in clams from this station (Brown and Luoma 1995; R.C. Kaufman, UC Davis, personal communication), and reflected the increased heavy-metal concentrations at station 4.1.

Current hypotheses to explain the apparent discrepancy in the clams' biomarker responses focus on salinity as a stress factor, but do not exclude the possible influence of chemical stressors. While $P$. amurensis can tolerate very low salinities (0.1 ppt), prolonged exposure to freshwater is lethal. At station 4.1, salinity is close to the species' lower tolerance limit, with extended periods of freshwater conditions during winter and spring. Our laboratory experiments suggest that there is a link between cellular stress-protein levels and salinity. For example, clams collected in December 1998 from a low-salinity station $(0.1 \mathrm{ppt})$ were not able to raise stressprotein concentrations in response to heat-shock (fig. 5A), a normal response to temperature stress, whereas clams from stations with higher salinities (5.6 ppt and $14.9 \mathrm{ppt}$ ) could (fig. 5B). In addition, clams exposed to low salinity $(0.1 \mathrm{ppt})$ in the laboratory had lower tissue concentrations of stress protein than clams exposed to medium (10 ppt) and high (27 ppt) salinities (table 2).

This is not easily explained. Asian clam is an osmo-conformer, which means they can rapidly (within 48 hours, R.C. Kaufman, UC Davis, personal communication) adapt to
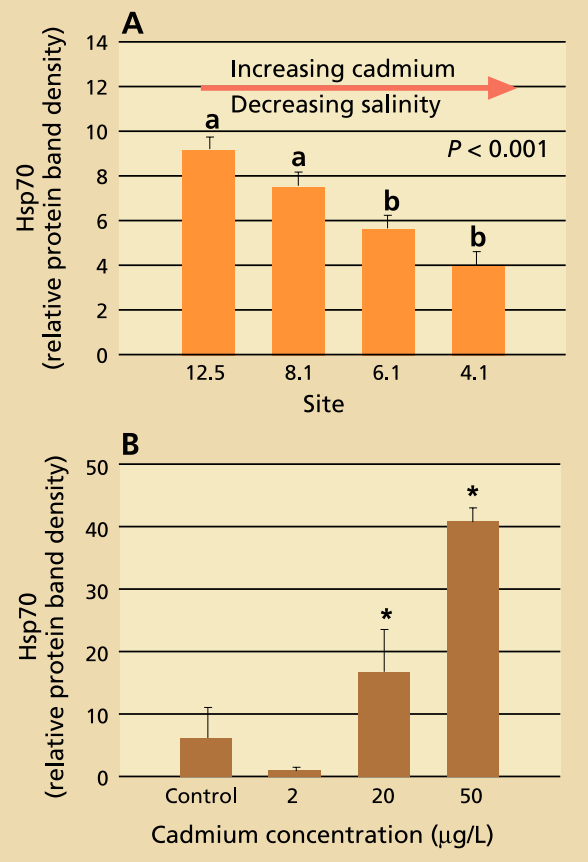

Fig. 3. (A) Average stress protein (hsp70) levels in Asian clam from four stations in northern San Francisco Bay. Six clams per site were collected monthly from July 1996 to January 1998. Group a is significantly $(P<0.001)$ different from group $b$.

(B) Average stress-protein levels in Asian clam $(n=6)$ after exposure to dissolved cadmium in the laboratory. * indicates significant difference $(P<0.05)$ from control and $2 \mu \mathrm{g} / \mathrm{L}$-exposed clams. Error bars represent standard errors of the mean.

changes in salinity by increasing or decreasing intracellular concentrations of certain amino acids (alanine and glycine betaine). Hsp70s perform important cellular functions but there is no indication that they are involved in osmo-regulation, the process animals use to adapt to changes in salinity, or that their concentrations are diluted selectively during osmo-adaptation.

A possible explanation could lie in the energetic cost of osmo-regulation, and the effect of energy depletion on the clam's ability to maintain proper cellular function. Osmo-regulation is very costly in terms of energy consumption. In clams from stations with the lowest salinities, concentrations of glycogen (a carbohydrate used by animals to store energy) were significantly reduced, and gradually increased toward stations with the highest salinities (C. Brown, USGS, Menlo Park, personal communication). Such a reduction in cellular energy reserves could compromise the clam's ability to increase cellular stress-protein
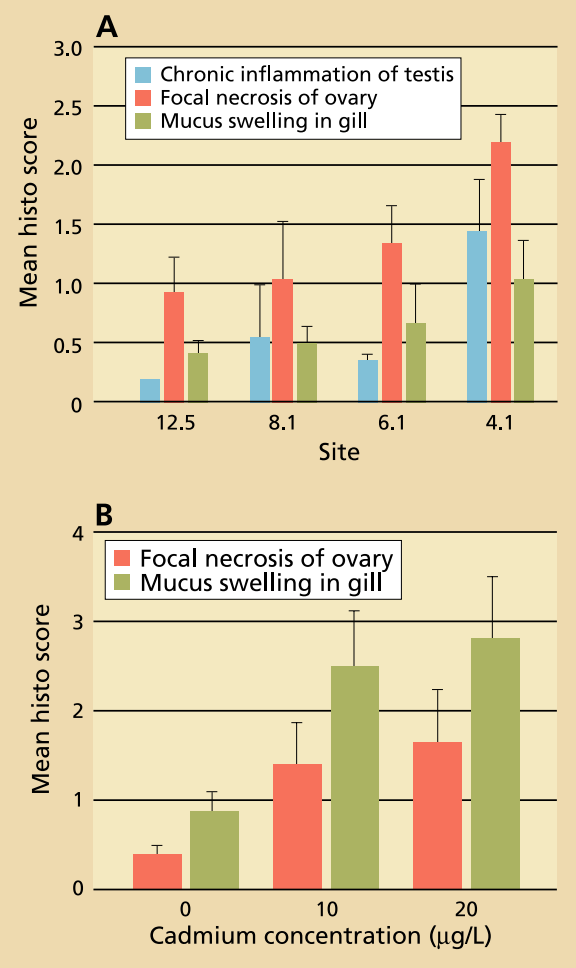

Fig. 4. (A) Results of histopathologic screening in Asian clam from four stations in northern San Francisco Bay. Ten clams per site were collected monthly from July 1996 to June 1997. (B) Average histopathologic screening scores in Asian clam $(n=10)$ after exposure to dissolved cadmium in the laboratory. Error bars represent standard errors of the mean.

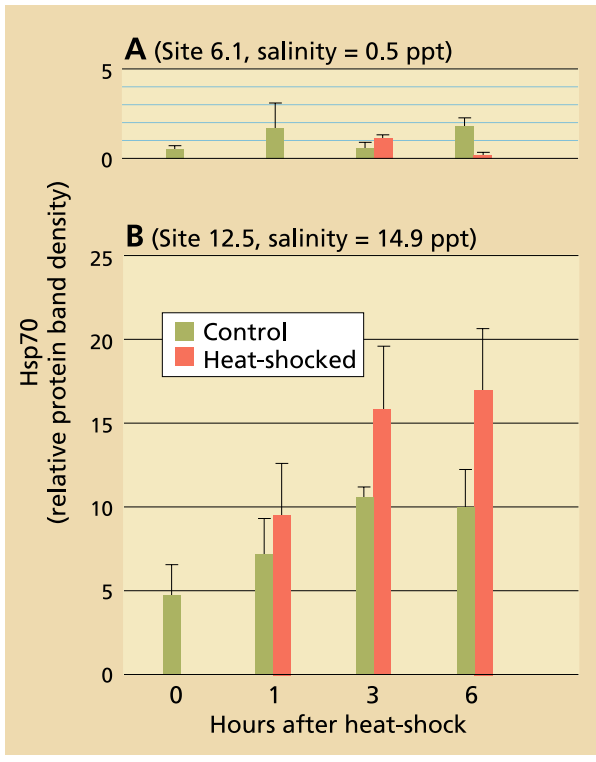

Fig. 5. Results of stress-protein (hsp70) analyses in Asian clam collected from northern San Francisco Bay stations in December 1998 and exposed to brief heat-shock ( $15 \mathrm{~min} . \mathbf{9 8}^{\circ} \mathrm{F}$ ) in the laboratory. Salinities at collection sites were (A) 0.5 ppt (site 6.1) and (B) 14.9 ppt (site 12.5). Clams from site 6.1 were unable to respond to heat-shock by increasing their cellular hsp70 concentrations. 


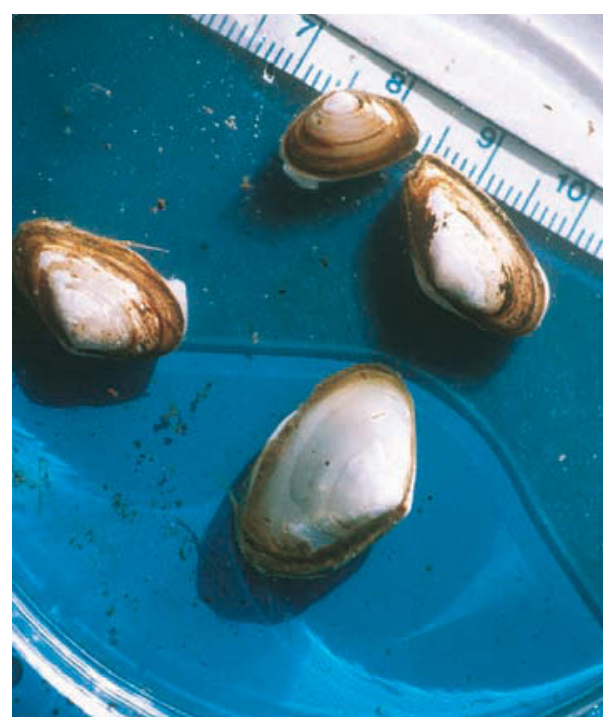

The nonnative Asian clam was introduced into San Francisco Bay in the mid-1980s. Clams were collected from various sites in the Delta and tested for stress proteins and tissue damage. Tissue damage was common at sites where heavy metal concentrations were highest and stress proteins lowest, potentially signaling an impairment of reproductive capacity and cellular protective responses.

concentrations in an effort to adapt to stress. This, in turn, may lead to higher susceptibility to other environmental stressors and reduced organism health. Protein synthesis and repair are energyintensive processes. Roberts et al. (1997) estimated that the total cost of protein synthesis under nonstressful conditions constitutes $20 \%$ to $25 \%$ of the energy budget of the bay mussel (Mytilus edulis) and repair of one damaged protein molecule, which is what stress proteins do, requires as much as 100 ATP (the energy "currency" of cells) molecules. Research shows that energy-

deprived cells are more heat-sensitive than controls, indicating that their normal heat-shock response may be disrupted, and establishing a link between reduced ATP levels and compromised stress-protein function (Feige et al. 1996).

\section{Consequences for organisms}

Despite these complex interactions, which we are still striving to understand, our results to date show that biomarkers can be useful indicators of sublethal effects or responses to environmental stressors, and that the failure to raise cellular stress responses can have severe consequences for the survival and health of organisms. Our medaka study demonstrated that earlystage fish embryos are more sensitive to certain environmental stressors because they lack the ability to raise cellular concentrations of certain stress proteins. Our study on clams showed that histopathology is a sensitive indicator of compromised organism health. We also learned that the ability to raise cellular stress responses can be compromised when organisms experience prolonged exposure to environmentally stressful conditions such as low salinity. It is possible that the high degree of osmo-regulation required at very low salinities depleted energy reserves and, in turn, rendered clams more susceptible to additional stressors such as heavy metals.

If this concept can be transferred to other species and stressors, these kinds of studies will improve our understanding about the mechanisms underlying the effects of multiple stressors on organisms. However, there is still a paucity of information on the complex interactions and mechanisms that govern biomarker responses. This lack of thorough functional databases can render the interpretation of results from field studies difficult, especially where results need to be linked to organism or population health. Nevertheless, biomarkers offer valuable mechanistic insights into sublethal physiological processes that will eventually elucidate the complex links between environmental conditions, stress responses, and organism and population health.

I. Werner is Research Scientist, Aquatic Toxicology Program, School of Veterinary Medicine, UC Davis; S.L. Clark is Laboratory Director, Pacific EcoRisk, Martinez, Calif.; and D.E. Hinton is Professor, Nicholas School of the Environment, Duke University, N.C. We thank Cory Koger and Swee Teh (UC Davis), and Sam Luoma, Cindy Brown and the crew of the RV Polaris (USGS, Menlo Park, Calif.) for their assistance in these projects. Mike Oliver, David Moon and two anonymous reviewers provided valuable comments on earlier drafts. This research was supported by a grant from the U.S. Environmental Protection Agency's Science to Achieve Results (grant \#R826940-01-1) program and the Center for Ecological Health Research, UC Davis. The histopathology research was supported by an ecotoxicology trainee fellowship from the UC Toxic Substances Research and Teaching Program's Systemwide Program in Ecotoxicology.

\section{References}

Baumann JW, Liu J, Klaassen CD. 1993. Production of metallothionein and heatshock proteins in response to metals. Fund Appl Toxicol 21:15-22.

Bennett WA, Moyle PB. 1996. Where have all the fishes gone? Interactive factors producing fish declines in the Sacramento-San Joaquin estuary. In: Hollibaugh JT (ed.). San Francisco Bay: The Ecosystem. San Francisco: Pacific Division, AAAS, California Academy of Sciences. p 519-42.

Brown CL, Luoma SN. 1995. Use of the euryhaline bivalve Potamocorbula amurensis as a biosentinel species to assess trace metal contamination in San Francisco Bay. Mar Ecol Progr Ser 124:129-42.

Carlton JT, Thompson JK, Schemel LE, Nichols FH. 1990. The remarkable invasion of San Francisco Bay, California (USA) by the Asian clam Potamocorbula amurensis. 1. Introduction and dispersal. Mar Ecol Prog Ser 66:81-94.

Clark SL, Teh SJ, Hinton DE. 2000. Tissue and cellular alterations in Asian clam (Potamocorbula amurensis) from San Francisco Bay: Toxicological indicators of exposure and effect? Mar Environ Res 50:301-5.

Feige U, Morimoto RI, Yahara I, Polla BS. 1996. Stress-Inducible Cellular Responses. Basel, Switzerland: Birkhauser Verlag. 512 p.

Feyrer F. 2000. Changes in fish diets in the San Francisco Estuary following the invasion of the clam Potamocorbula amurensis. IEP Newsletter 13(4):21-6.

Hamm JT, Wilson BW, Hinton DE. 1998. Organophosphate-induced acetylcholinesterase inhibition and embryonic retinal cell necrosis in vivo in the teleost Oryzias latipes. Neuro Toxicol 19(6):853-70.

Huggett RJ, Kimerle RA, Mehrle Jr PM, Bergman HL. 1992. Biomarkers: Biochemical, Physiological and Histological Markers of Anthropogenic Stress. Boca Raton, Fla.: Lewis. $346 \mathrm{p}$.

Iwama GK, Thomas PT, Forsyth RB, Vijayan MM. 1998. Heat-shock protein expression in fish. Rev Fish Biol Fisheries 8:35-56.

Kimmerer WJ, Orsi JJ. 1996. Changes in the zooplankton of the San Francisco Bay Estuary since the introduction of the clam Potamocorbula amurensis. In: Hollibaugh JT (ed.). San Francisco Bay: The Ecosystem. San Francisco: Pacific Division AAAS, California Academy of Sciences. p 403-24.

Marty GD, Nunez JM, Lauren DJ, Hinton DE. 1990. Age-dependent changes in toxicity of N-nitroso compounds to Japanese medaka (Oryzias latipes) embryos. Aquat Toxicol 17:45-62. 
Nichols FH, Thompson JK, Schemel LE. 1990. The remarkable invasion of San Francisco Bay, California (USA) by the Asian clam Potamocorbula amurensis. 2. Displacement of a former community. Mar Ecol Prog Ser 66:95-101.

Roberts DA, Hofmann GE, Somero GN. 1997. Heat-shock protein expression in Mytilus californianus: Acclimatization (seasonal and tidal-height comparisons) and acclimation effects. Biol Bull 192:309-20.

Roth DA, Taylor HE, Domagalski J, et al. 2001. Distribution of inorganic mercury in Sacramento River water suspended colloidal sediment material. Arch Environ Contam Toxicol 40(2):161-72.

Sanders BM. 1993. Stress proteins in aquatic organisms: An environmental perspective. Crit Rev Toxicol 23:49-75.

Soimasuo MR, Werner I, Villalobos A, Hinton DE. 2001. Cytochrome P450 1A1 and stress protein induction in early life stages of medaka (Oryzias latipes) exposed to trichloroethylene (TCE) soot and different fractions. Biomarkers 6(2):133-45.

Teh SJ, Clark SL, Brown CL, et al. 1999. Enzymatic and histopathologic biomarkers as indicators of contaminant exposure and effect in Asian clam (Potamocorbula amurensis). Biomarkers 4(6):497-509.

U.S. Geological Survey. 1998. Pesticides in storm runoff from agricultural and urban areas in the Tuolumne River basin in the vicinity of Modesto, California. WaterResources Investigations Report 98-4017, National Water Quality Assessment Program. Sacramento, CA. 17 p.

Werner I, Deanovic LA, Connor V, et al. 2000. Insecticide-caused toxicity to Ceriodaphnia dubia (Cladocera) in the Sacramento-San Joaquin River Delta, California, USA. Environ Toxicol Chem 19(1):215-27.

Werner I, Hinton DE. 1999. Field validation of hsp70 stress proteins as biomarkers in Asian clam (Potamocorbula amurensis): Is downregulation an indicator of stress? Biomarkers 4(6):473-84.

Werner I, Hinton DE. 2000. Spatial profiles of hsp70 proteins in Asian clam (Potamocorbula amurensis) in northern

San Francisco Bay may be linked to natural rather than anthropogenic stressors. Mar Environ Res 50(1-5):379-84.

Werner I, Hollibaugh JT. 1993. Potamocorbula amurensis: Comparison of clearance rates and assimilation efficiencies for phytoplankton and bacterioplankton. Limnol Oceanogr 38(5):949-64.

Werner I, Koger CS, Hamm JT, Hinton DE. 2001. Ontogeny of the heat-shock protein, hsp70 and hsp60, response and developmental effects of heat-shock in the teleost, medaka (Oryzias latipes). Environ Sci 8(1):13-30.

Werner I, Nagel R. 1997. Stress proteins hsp60 and hsp70 in three species of amphipods exposed to cadmium, diazinon, dieldrin and fluoranthene. Environ Toxicol Chem 16(11):2393-403.

Zuegel U, Kaufmann SHE. 1999. Role of heat-shock proteins in protection from and pathogenesis of infectious diseases. Clin Microbiol Rev 12(1):19-39.

\section{Landscape changes in Nevada County reflect social and ecological transitions}

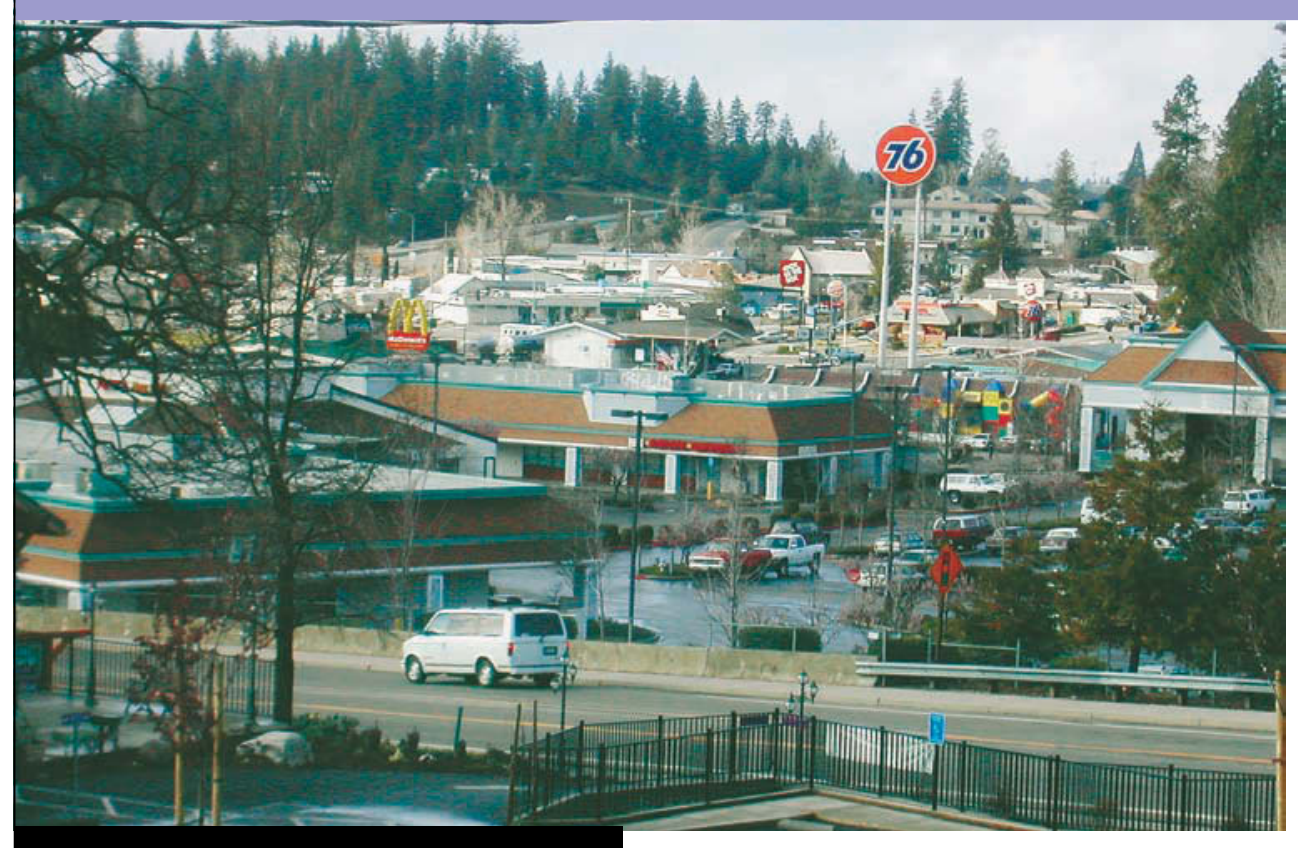

Peter A. Walker Sarah J. Marvin Louise P. Fortmann $\nabla$

Large-scale migration of urban people seeking a better quality of life in rural places has generated considerable concern about "rural sprawl." In a multimethod, fine-scale, longitudinal study of land ownership and use in Nevada County, we found that this quintessential "exurban" community reveals a complex story of interacting social and ecological change with some reasons for concern, but also optimism. Land-use data from 1957 to 2001 shows dramatic fragmentation of the county's landscape as a result of increased residential use. The full scale of this transition is not visible because many parcels that are already zoned for further subdivision and residential use remain undeveloped. The related ecological changes have been mixed so
About an hour's drive east of Sacramento in the Sierra Nevada, Nevada County typifies expansion of the "exurbs," which have experienced dramatic population growth in recent years. Grass Valley (Brunswick basin) is a small but growing city in the primarily rural, agricultural and residential county.

far, with tree cover and riparian areas recovering from historic mining, ranching and timber harvesting. These changes are not incidental: many residential owners expressed a strong conservation ethic. However, ecologically harmful effects of increased residential use are present as well. In surveys and interviews, rural-residential owners revealed conflicting feelings about their changing landscape: most are concerned about preserving their quality of life and preventing the ecological impacts of further growth, but also do not want additional government regulations. Research on a fine scale into the cultural basis of ecologically beneficial and harmful rural-residential land-use practices can assist policymakers in crafting innovative and effective growth-management institutions. 